\title{
外傷性脾損傷の検討
}

日本医科大学救命救急センター

$$
\begin{array}{lllll}
\text { 安田和 弘* 辺 見 } & \text { 弘** 山 本 保 博 } \\
\text { 益子 邦 } & \text { 洋 } & \text { 大 塚 敏 文*** } & &
\end{array}
$$

\section{A STUDY ON SPLENIC INJURY}

Kazuhiro YASUDA*, Hiroshi HEMMI**, Yasuhiro, YAMAMOTO

Kunihiro MASHIKO and Toshifumi, OTSUKA***

The Department of Critical Care Medicine, Nippon Medical School

外傷性脾損傷の治療としては脾全摘が広く行なわれれてきた。しかし，近年重症脾摘 後敗血症 (Overwhelming postsplenectomy sepsis) が注目され, 脾を温存することの 重要性がさけばれている，われわれは，過去38例の外傷性脾損傷を释験したのでここに それををとめ，手術時肉眼所見をもとにして5 型に分類し，その治療法（術式）の原則 を示す。

脾損傷の受傷機転としては，交通災害・高所墜落が多い，そのため，脾単独損傷は38 例中 2 例之少なく、胸腹部を中心に合併損傷を有する症例が多い，手術時肉眼所見より 脾損傷を分類すると，I 型二被膜損傷，6 例。II 型二被膜下血腫． 0 例．III=単純性実質 損傢， 9 例. IV 型=複雑性実質損傷（脾門部血管損傷を伴う実質損傷），7例．V 型=全 脾破裂，4例。但し，手術不能例，所見不明例は例数に含まれていない，治療としては， 手術不能例 7 例を除いた31例中25例 $(81 \%)$ に脾全摘を施行した。 6 例では脾全摘をせ す，局所止血製郕を当てるのみ 1 例，脾縫合 3 例，脾部分切除 1 例，非手術療法（保存 的療法）1例である，最近は脾全摘が減少傾向にあり，脾温存術が増加している。治療 成績は31例中10例死亡したが，脾を温存した 6 例では，頭部合併損傷による脳死の 1 例 を除いた 5 例が生存し，再出血，仮珄のう胞といった合併症は認めていない．

われわれは分類にもとづき，それぞれ選択すべき治療法（㭪式）をまめたＩ型：局 所止血製戍を当てるのみ，あるいは縫合ＩII型；小さくかつ増大傾向のない時は処置を 施さない，しかし，大きな血腫あるいは増大傾向のみられる時には被膜切開・血腫除去 の上繾合する. III 型：縫合. IV 型：部分切除. V 型：全摘.しかし，合併損傷を有した り全身状態不良で脾の処理を急ぐ必要がある時には，損傷程度にかかわらず脾全摘を施 行するのを原則とする.

\section{I. はじめに}

脾損傷は頻度の高い外傷であり腹腔内出血を起こす 原因の代表的なものの一つである。その治療法として は脾全摘が行なわれることが多い.しかし，免疫能 低下による重症脾摘後敗血症 (overwhelming post-

“助手 **助教授 ***主任教授 splenectomy sepsis)が注目され，近年脾を温存するこ との重要性が強調されている。

ここに，われわれが過去に経験した外傷性脾損傷 38 例について検討を加学，損傷程度别分類とその治療を 示す。

\section{II. 対 象}

日本医科大学救命救急センターにおいて, 昭和50年 
4 月の開設時より，昭和57年 4 月までの 7 年 1 力月間 に38例の外鹪性脾損傷を経験した。内訳は，男性34例, 女性 4 例で, 年龄は 1 歳一74歳, 平均年柃28.6歳であ。 た.

\section{III. 受鹪機転，合併損稘}

受塲機転としては交通炎害が最も多く，次いで高所 墜落，その他の鈍的外傷，刺創が続く(図 1 )。また。 合併損鹪をみてみると，脾単独損傷は2例 $(5.3 \%)$ と 小なく，他の36例は合併損傷を有しており，胸部，腹 部が多い(表 1 )。脾単独損傷が少ないのは，当施設が 第三次救急施設であり，重症外傷患者が搬送されてく るためと考えられる．胸部合併損傷は，胸骨・助骨、 折が16例と最も多く，左第VII助骨を中心としておこる

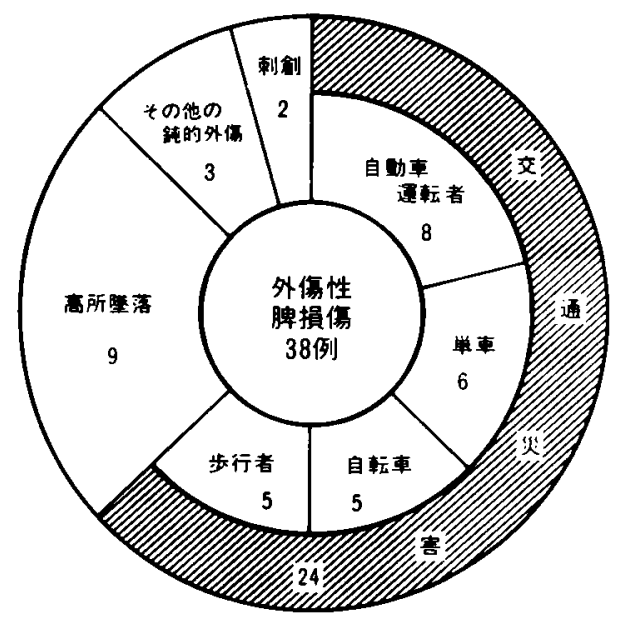

$$
\begin{gathered}
\text { 日本医科大学 } \\
\text { 数命教急センター }
\end{gathered}
$$$$
\text { 1975.4.1. 1982.4.30 }
$$

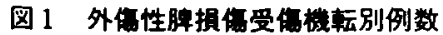

総数38例. 男 34 例, 女 4 例, 年此命 1 - 74歳(平均 28.6 歳)

\section{表 1 合併損傝}
A 、脾単独損偤
2 例 $(5.3 \%)$
B . 合併損傷あり

\begin{tabular}{|c|c|c|}
\hline 頭 & 部 & 17 例 $(18.4 \%)$ \\
\hline 胸 & 部 & 23 例 $(60.5 \%)$ \\
\hline & 部 & 25 例 $(65.8 \%)$ \\
\hline & ·骨盤 & 12 例 $\left(31.6^{\circ} \%\right)$ \\
\hline
\end{tabular}
36 例 $(94.7 \%)$

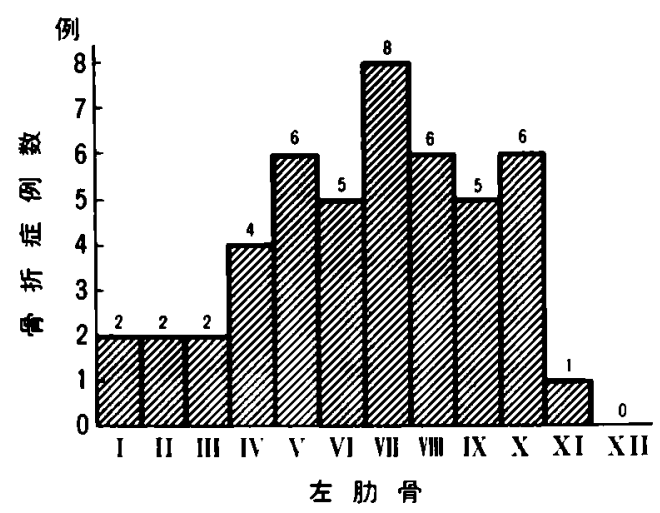

図 2

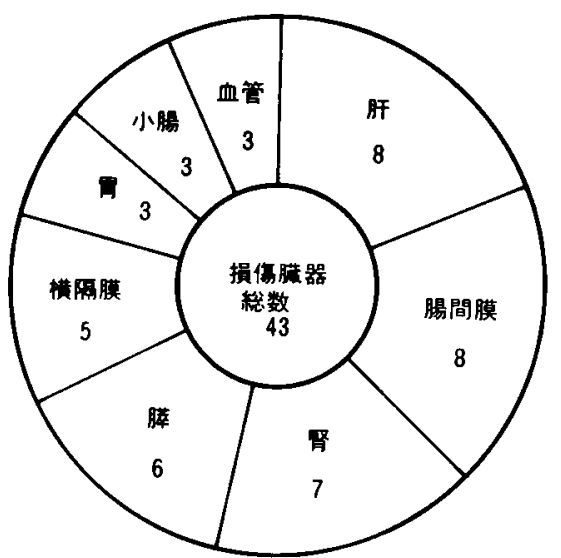

図 3 腹部合阱損侮25例

(図 2 ). 次いで血胸・気胸10例，肺挫傷・肺破裂 9 例, 心大血管破裂 3 例と続く，腹部合併損傷は，図3のご とく，肝・腸間膜・腎・苹・横隔膜等にみられる。

\section{IV. 損賃程度別分類}

脾損傷の分類は過去いろいろなされている(1)が， われわれ汢手術時肉眼所見をむとにして程度別にI 〜 V 型に分類した（図 4 ).I型二被膜損偒 (Capsular tear）：これは被膜のみに損傷がみとめられるむので, 手術を施行し所見の明らかな26例中 6 例がこの分類に 含まれる。II型二被膜下血腫 (Subcapsular hematoma）：この型の損偒の報告があり項目を設け たが、まだ経験していない．III型＝単純性実質損傷 (Simple parenchymal fracture)；脾門部血管損傷を 伴わない夷質損傷であり，26例中 9 例であったＩV 型二複雑性奏質損傷 (Complicated parenchymal fracture）：脾門部血管損傷を伴 5 実質損傷で，7例み られた。 $\mathrm{V}$ 型二全脾破裂（Total splenic disruption）： 


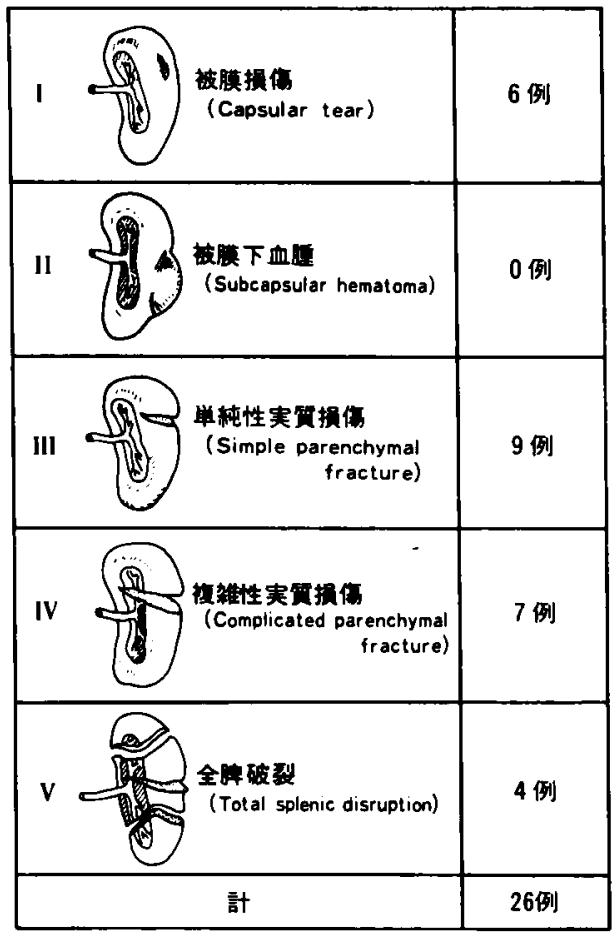

图 4 䏷損灀の分類

脾全体に及ぶ破裂で，4 例みられた。

\section{V. 治 彯}

脾全摘を 25 例施行しており，81\%を占めている．し かし，1981年以降は 9 例中 5 例，56\% と减少し，脾温 存術が増加している，局所に止血製剤を当てるのみの 処置例 1 例，脾絴合 3 例，脾部分切除 1 例施行した。 非手術療法（保存的療法）を行なった 1 例もある（表 2 ).

局所止血製剤としては，酸化セルロース（オキシセ 几®)，ゼラチン(スボンゼル®)を用いている，脾縫 合，脾部分切除の具体的方法は，图5のごとく，系を 結ぶ際組織が引ききれれよらにテフロンフェルトを 当て，それを通して水平マットレス䋖合を行なってお ク，系はダクロン米あるいは腸線を使用している。こ の際，あらかじめ十分脾を可動化し，良好な梘野のむ とで操作を行ならことの重要性はいらまですない゙。

治療成樍は，多発外傷あるいはDead on arrival （DOA）にて手術不能であった 7 例を除いた 31 例中10 例死亡し，死亡率32\%であった，脾を温存した 6 例で は，頭部合併損傷による脳死の 1 例を除いた 5 例が生 存し，再出血，仮性のう胞といった合併症は現在まで 認めていない。
偆 2 治

\begin{tabular}{|c|c|c|c|c|}
\hline \multicolumn{2}{|r|}{ 治法 } & 症例数 & 死亡数 & 死亡聿 \\
\hline \multirow{4}{*}{$\begin{array}{l}\text { 手 } \\
\text { 復 } \\
\text { 行 } \\
\text { 例 }\end{array}$} & 止血椠削のみ & I例（3\%） & O 例 & $0 \%$ \\
\hline & 䯏糧合 & $3(10)$ & 1 & 33 \\
\hline & 部分切除 & $(3)$ & 0 & 0 \\
\hline & 腄全抹 & 25 (B1) & 9 & 36 \\
\hline & 非手術排法 & $(3)$ & 0 & 0 \\
\hline & 計 & 31 例 & 10例 & $32 \%$ \\
\hline
\end{tabular}

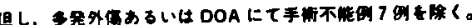

脾縫合法

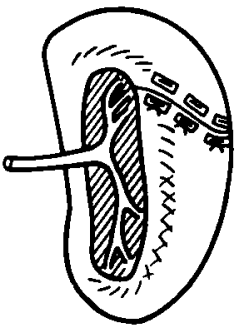

脾部分切除法

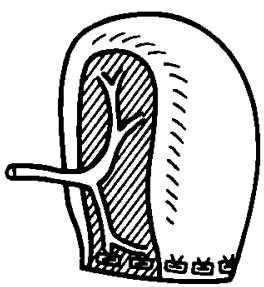

テフロンフェルトを当て、ダクロン类または 腸線にて水平マットレス繾合

图 5

VI. 症 例

症例 1 I.H. $13 \hat{\jmath}$

現病歴：自転車で走行中，乗用車と衝突し受倁. 四 肢は動かすが意識なし。すぐ当センターへ搬送される。

入室時現症：血王 $126 / 80 \mathrm{mmHg}$ ，心拍数 $120 /$ 分，呼 吸は线く速い。昏睡状態。

胸部 X-P：左第 V V VII助骨骨折，左肺挫傷

腹部 X.P(図 6)：傍結腸溝開大，骨盤腔内液体詝留 をみとめる。

腹腔詿唫穿刺：陽性

CT スキャン（図 $7 \mathrm{a})$ ：脾実質内に低吸収域がみと められる.

血管撮影(選択的脾動脈造影)（図 $7 \mathbf{b}$ )：明らかに脾 破裂がみとめられるが，大きな血管の損傷なし。

輸血1400mlによりバイタルサイン安定し, 意識も回 復. 手術をせずに軽快。

症例 2 T.T. 6 今

主訴：胸痛, 呼吸困難

現病歴：道路にとび出し，乗用車には好られる。近 医に搬送されるす，胸痛，呼吸困難強く当センターへ 


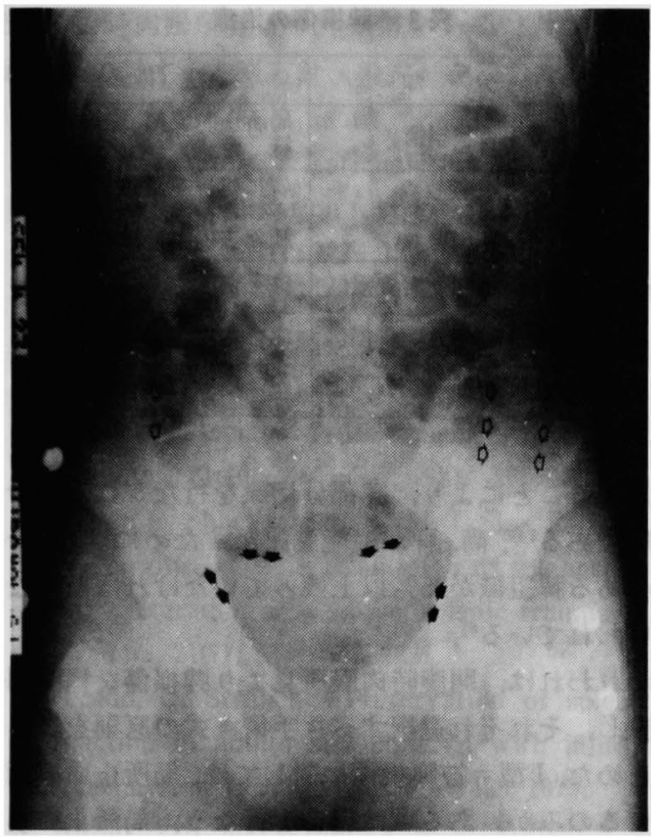

图 6

$\Rightarrow$ 傍結腸溝開大. $\rightarrow$ 骨盤内液体詝留像 (dog's ears sign)

\section{転送される。}

入室時現症：血压 $110 / 52 \mathrm{mmHg}$ ，チアノーゼ(十). 胸部に皮下気腫, 血性痰多量.

胸部 X-P：两側肺挫傷。右気胸.

腹腔試験穿刺：陽性.

治療：胸腔ドレーン指入。血王低下し緊急開腹術施 行. 脾下極近くより脾門部に達する断裂あり (IV 型).
部分切除施行(図 8). 術後経過良好で，合併症なく軽 快す。

\section{VII. 考 察}

脾の免疫機能としては， $\mathrm{T}$ 細胞， $\mathrm{B}$ 細胞を調節し， 抗体を産生し, 液性免疫, 細胞性免疫の両者に関与す るばかりでなく，非特異的免疫に拈いてす大きな役割 を担っている5). 細網内皮系組織の一つとして, 脾内、 フロファージは血液中の異物を鿖食し排除する。また， 好中球の貪食能を刺激する tuftsin は脾でのみ産生さ れる677).よって, 脾全摘を受けた患者では種々の免疫 学的異常がみられることが明らかになってきた5)899. 具体的には, IgMの減少(IgG, IgAに関しては一致し た結果は得られていない). properdinの減少, tuftsin の産生中止, マクロファージの mobilization の遅延で ある。

以上のごとく脾の免疫機能が認識されたのは最近で あり，従来は脾全摘を施行しても何ら障害を残さない と考えられてきた．脾損傷の治療法としても，その程 度の軽重を問わず脾全摘が行なわれることが多かっ た。迅速に施行でき, 術後の再出血, 仮性のら胞といっ た合併症がないという利点すあり広く普及したわけで ある.しかし，1952年 King \& Schmacker が，先天性 球状赤血球症で脾摘を行なった 5 例を注意深く観察 し, 脾摘後の敗血症に関して初めて報告した ${ }^{10)}$.さらに 1973年 Singer は688例の外傷性脾損傷による脾摘症例 中10例が敗血症に陥り， $5 ち 4$ 例が死亡したことを報 告した ${ }^{11)}$. その後も次々と脾摘後敗血症々例の報告が なされ，脾摘症例の敗血症による死亡率が正常人の 50〜200倍であることが明らかにされた ${ }^{1}$. 脾摘後敗血

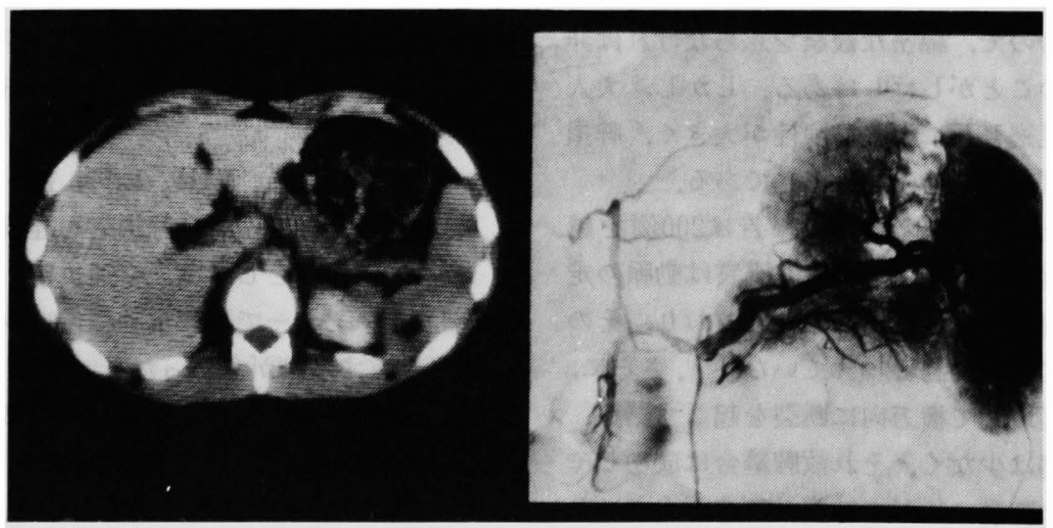

（a）脾実質内に低吸収域をみとめる.

（b）無血管野の存在により，膊破裂がわかる。

图 7 


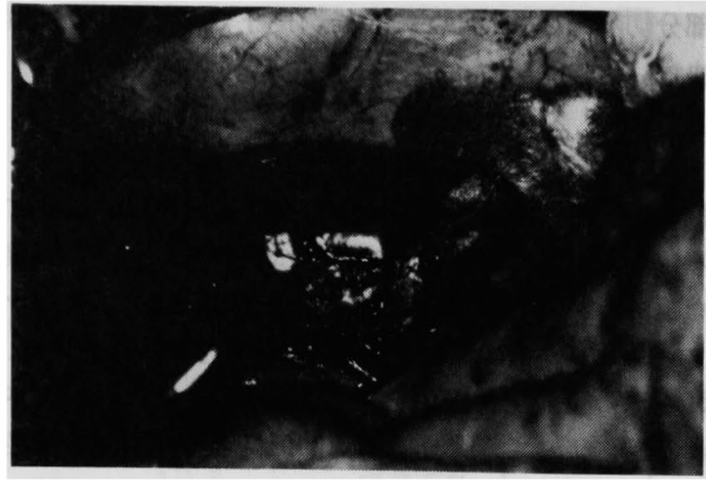

図 8 脾部分切除；脾下半を切除し，テフロンフェル トを当て、マットレス释合を行ない断端を止血。

症の症状は激烈で, 突然呕気・呕吐・頭痛・意識障害 で始まり，最初の症状が出てから $2 \sim 3$ 時間以内に死 亡することもある゙. このように脾全摘の危険性が認 識され, さらに免度葴器としての脾の機能が明らかに されるについて，脾を残すことの重要性がさけばれる よらになってきた。

脾摘後敗血症は，年齢的には小児に罹患率が高いが， あらゆる年代にみとめられる，発病の時期は，約半数 は 1 年以内に起こり, 大多数は 2 年以内に起っている が8), time-limit はなく術後25年で発病した報告すあ る. 起炎菌としては, Pneumococcusか最も多く, Meningococcus, E. coli, Hemophilus influenzae, Staphylococcus, Streptococcusの順となってい $3^{1) 9}$.

脾損傷において脾を温存する方法はいくつかあり， 次々とその成功例が報告されてきた。一つは，非手術 療法（保存的療法）であり，約100例の小児症例の報告 がある12).小児では自然止血することが多く，輸血絶対 量が少なくてすむので，綿密な観察を意らなければ非 手術療法が可能のことがしばしばある。しかし，大人 では合併損傷を見逃し死に至る危険性が大きく，脾損 傷の診断がつけば手術に踏み切るべきである。

脾縫合，脾部分切除の成功例の報告は200例を越 え ${ }^{5) 7}$ ，その安全性が確立してきた。脾実質は動脈の走 行により3〜6個の動脈性区域に分かれており，その 間には原則として吻合は認められていない、13.さらに, 多くの脾損傷は区域間で横方向に断裂を起こす結果, 大きな血管の損傷は少なく，それ故脾縫合は成功しゃ すい. 特に小児は脾髄に比して被膜の割合が大きいた め, 絴合止血が容易である゙!。た, 脾動脈は脾に入る 前に 2 - 5 本に分岐している(3)ので，損傷区域の枝を
表 3 腪損俨の治療

\begin{tabular}{|c|c|}
\hline 分 & 治撩法 (術式) \\
\hline I 型：被膜損賃 & $\begin{array}{l}\text { 局所止血彆剂 } \\
\text { 維 合 }\end{array}$ \\
\hline 且型：被膜下血腫 & $\begin{array}{l}\text { 特に処置を㳬さずあ } \\
\text { るいは被膜切開・血 } \\
\text { 腫除去の上，綎合 }\end{array}$ \\
\hline 四型：戦純性実質損賃 & 䋖 合 \\
\hline IV型：複雑性実質指伤 & 部分切除 \\
\hline V型：全脾破裂 & 全 摘 \\
\hline
\end{tabular}

結禁することにより，脾部分切除を行なうことは十分 可能である ${ }^{14)}$. 尚, 脾が機能を果たすためには, 十分循 環のある脾組織が25\%以上残っていなければならない といわれている8).

われわれは，開腹時肉眼所見より脾損傷を程度別に 分類し，それぞれ選択すべき手術々式の原則を表了に まとめた. I 型二被膜損傷に対しては, 局所止血製剂を 当てるのみか，あるいは繾合を行なう，局所止血製郕 としては，酸化せルロース，ゼラチンがよく用いられ ている. microfibriller collagen は吸収性の局所止血製 剂で，粘着性が高く血小板を凝集させ止血効果が高い と報告されているが5)，まだわが国では市販されてい ない. II 型＝被膜下血腫に対しては，小さくかつ増大 傾向のないときは特に処置を施さない，しかし，大き な血腫あるいは增大傾向のみられる例では，被膜切 開・血腫除去の上䋖合する．III 型＝単純性実質損傷に 対しては繾合がよい.IV 型=複雑性実質損傷に対して は，脾門部で血管を処理し部分切除するのがよい、V 型二全脾破裂は全摘を原則としている。

しかしながら，脾全摘が縫合・部分切除に比べてよ り迅速に施行し得るといら点に関して異論は少なく， 他に合併損傷があったり，全身状態不良で脾の処理を 急ぐ必要がある場合には脾全摘を施行すべきであると 考交る。

\section{VIII. 結 語}

1）過去38例の外傷性脾損傷を経験した。

2）受傷機転としては, 交通災害, 高所墬落が多い.

3）当センターでは脾単独損傷は少なく,胸腹部合併 損傷を有する例が多かった。

4）治療としては脾全摘施行例が多いが,脾摘後敗血 症が問題となってきて，最近は減少してきている。か わりに，局所止血製剂を当てるのみ，縫合，部分切除 及び非手術療法といった脾温存法が增加してきてい る. 
5）手術時肉眼所見より脾損傷を $\mathrm{I} \sim \mathrm{V}$ 型に分類し， それぞれに対する治療方針（術式）を示した。

$$
\text { 女 嗝 }
$$

1) Roger Sherman: Rationale for and methods of splenic preservation following trauma. Surg. Clin. N. Am., 61(1) : 127-134, 1981.

2）前川和彦：外伤性脾損傷の取り扱い。外科診療, （昭和56. 5)：541-548， 1981.

3) Audrey, C. Traub and Hohn F., Perry, Jr.: Injuries associated with splenic trauma. J. Trauuma, 21(10) : 840-847, 1981.

4) Steven R. Shackford, Michael J. Sise, Richard, W. Virgilio, et al.: Evaluation of splenorrhaphy: A grading system for splenic trauma. J. Trauma, 21(7) ; 538-542, 1981.

5) Gerald, O. Strauch: Preservation of splenic function in adults and children with injured spleens. Am. J. Surg., $137:$ 478-483, 1979.

6) Najjar, V.A. and Nishioka, K.: 'Tuftsin': A natural phagocytosis stimulating peptide. Nature, 228: 672-673, 1970.

7) Roger Sherman: Perspectives in management of trauma to th spleen: 1979 presidental address, American association for the surgery of trauma. J. Trauma, 20(1) : 1-13, 1980.

8) William L. Buntain and Hugh B. Lynn: Splenorrhaphy: Changing concepts for the traumatized spleen, Surgery, $86(5): 748-760$, 1979.

9）沖永功太：脾摘患者と感染症，医学のあゆみ， 115 (10): 801-808, 1980.

10) King, H. and Schmacker, H.B. Jr.: Splenic studies: I. Susceptibility to infection after splenectomy performed in infacny. Ann. Surg., $136: 239-242,1952$.

11) Singer, D.B.: Postsplenectomy sepsis, Perspect. Pediat. Pathol., 1 : 285-311, 1973.

12) Sigmund, H. Ein, Barry Shandling, James, S. Simpson, et al.: Nonoperative management of traumatized spleen in children: How and Why. J. Pediatr. Surg., 13(2) : 117-119, 1978.

13）平松京一編：脾動脈の解剖, 腹部血管の $\mathrm{X}$ 線解剖 図譜, p. 112-121, 1982.

14) Leon Morgenstern and Stephan J. Shapiro: Techniques of splenic conservation. Arch. Surg., 114 : 449-454, 1979. 